\title{
Dampak Perkembangan Uang Elektronik terhadap Efektivitas Kebijakan Moneter di Indonesia
}

\author{
Ciplis Gema Qori'ah" ${ }^{\mathrm{a}, *}$, Yulia Indrawati ${ }^{\mathrm{a}}$, Adhitya Wardhono ${ }^{\mathrm{a}}$, \& M. Abd. Nasir ${ }^{\mathrm{a}}$ \\ ${ }^{a}$ Fakultas Ekonomi dan Bisnis Universitas Jember
}

\begin{abstract}
This study aims to analyze the impact of electronic money developments on the effectiveness of monetary policy in Indonesia. The analysis method used was the estimation of Structural Cointegrating Vector Autoregressive (SCVAR) with a time series observation period of 2009.1-2019.12. The results show that electronic money does not have an inflationary impact in the long and short term. The interest rate instrument is effective in controlling the speed of the circulation of electronic money. The increase in economic growth in the long and short term has no effect on the increase in electronic money transactions. Likewise, the increase in electronic money transactions in the long term has not been able to be followed by economic growth. As for credit, electronic money does not have a significant impact in the short term. However, in the long term, the increase in credit is followed by an increase in digital transactions.
\end{abstract}

Keywords: electronic money; inflation; output; monetary policy

\begin{abstract}
Abstrak
Pertumbuhan penggunaan uang elektronik mengalami perkembangan yang pesat, terlihat dari volume, nilai transaksi, dan preferensi masyarakat yang makin meningkat. Studi ini bertujuan untuk menganalisis dampak perkembangan uang elektronik terhadap efektivitas kebijakan moneter di Indonesia. Metode analisis yang digunakan adalah Structural CointegratingVector Autoregressive (SCVAR) dengan periode observasi 2009.1-2019.12. Hasil studi menunjukkan bahwa uang elektronik tidak menimbulkan dampak inflasioner, baik dalam jangka panjang dan pendek. Instrumen suku bunga cukup efektif dalam mengendalikan kecepatan perputaran uang elektronik. Kenaikan pertumbuhan ekonomi dalam jangka panjang dan pendek tidak memberikan pengaruh terhadap kenaikan transaksi uang elektronik. Begitu pula kenaikan transaksi uang elektronik dalam jangka panjang belum mampu diikuti oleh pertumbuhan ekonomi. Uang elektronik tidak memberikan dampak yang signifikan terhadap kredit dalam jangka pendek, tetapi dalam jangka panjang potensi kenaikan kredit diikuti oleh meningkatnya transaksi secara digital.
\end{abstract}

Kata Kunci: uang elektronik; inflasi; output; kebijakan moneter Kode Klasifikasi JEL: E41; E31; E49; E52

*Alamat Korespondensi Penulis: Jln. Kalimantan No. 37 Kampus Tegalboto Sumbersari Jember. E-mail: ciplisqoriah@gmail.com. 


\section{Pendahuluan}

Dinamika sistem pembayaran digital memberikan implikasi penting dalam sistem keuangan di Indonesia dan hal ini sejalan dengan peningkatan kebutuhan masyarakat yang makin cepat dan beragam. Selain itu, faktor kemudahan dan efisien biaya juga merupakan alasan mendasar masyarakat untuk lebih memilih pembayaran non tunai (Ismanda, 2019; Lintangsari et al., 2018; Fatmawati \& Yuliana, 2019). Akselerasi sistem pembayaran digital mendorong pergeseran preferensi digitalisasi masyarakat yang sebelumnya lebih banyak menggunakan uang tunai. Dengan meningkatnya transaksi non tunai, akan menimbulkan transparansi dalam perputaran uang dan dapat mengurangi jumlah permintaan uang tunai (Forrest et al., 2018; Popovska-Kamnar, 2014). Bank Indonesia selaku otoritas dalam pengaturan sistem pembayaran telah mengeluarkan regulasi melalui Peraturan Bank Indonesia (PBI) Nomor 20/6/PBI/2018 tentang Uang Elektronik. Bahkan saat ini tercatat, banyak bermunculannya perusahaan financial technology dengan beragam inovasi layanan jasa pembayaran digital. Bank Indonesia juga telah membangun kerja sama dalam bentuk open banking dalam memitigasi bermunculannya perbankan maya (shadow banking). Begitupun upaya dalam mempermudah sistem pembayaran, Bank Indonesia juga telah mengeluarkan sistem Quick Response Indonesian Standard (QRIS) pada awal tahun 2020. Dalam rangka menjamin kelancaran sistem baru tersebut, Bank Indonesia telah meletakkan dasar kebijakan pada empat pilar, yaitu peningkatan keamanan, efisiensi, perluasan akses, dan perlindungan konsumen (Bank Indonesia, 2019).

Perkembangan transaksi dalam penggunaan uang elektronik mengalami kenaikan yang cukup signifikan. Pada Gambar 1 menunjukkan kenaikan volume dan nilai transaksi uang elektronik sejalan dengan meningkatnya jumlah uang yang beredar di masyarakat. Tercatat volume dan nilai transaksi uang hingga akhir bulan November tahun 2018 mencapai 5,19 triliun rupiah atau naik sebesar 216,46 persen dibandingkan pada bulan November tahun 2017. Sementara itu, pertumbuhan nominal mencapai 216,46 persen, volume transaksi uang elektronik juga meningkat 157,31 persen menjadi 330,67 juta transaksi dari November 2017 yang mencapai 128,51 juta transaksi. Sampai November 2018, jumlah uang elektronik yang beredar tercatat sebanyak 152,07 juta rupiah atau meningkat 33,72 persen dibanding dengan tahun sebelumnya sebesar 113,72 juta rupiah. Sementara itu, ketersediaan infrastruktur berupa mesin electronic data capture (EDC) juga mengalami kenaikan pada tahun 2017 mencapai 691.331 unit menjadi 923.624 unit pada tahun 2018. Hal ini juga dikuti dengan jumlah instrumen uang elektronik yang beredar dari 90.003 .848 juta rupiah pada tahun 2017 menjadi 167.205.578 juta rupiah pada tahun 2018 (Bank Indonesia, 2019). Grafik perkembangan transaksi dan infrastruktur uang elektronik di Indonesia dapat dilihat pada Gambar 1.

Akselerasi sistem pembayaran elektronik yang makin cepat berimplikasi pada kerangka operasional kebijakan moneter dan kemampuan bank sentral dalam menggunakan suku bunga sebagai instrumen dalam mencapai sasaran akhir 


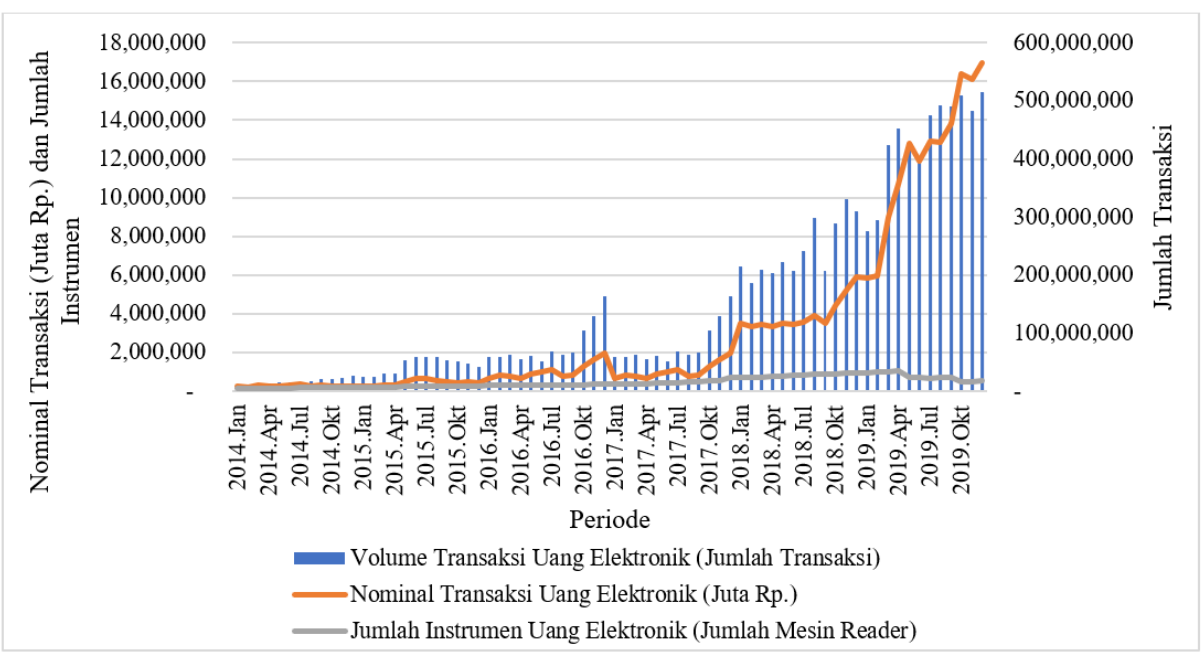

Gambar 1: Perkembangan Transaksi dan Infrastruktur Uang Elektronik di Indonesia Sumber: Bank Indonesia (2019)

kebijakan moneter (Durgun \& Timur, 2015; Ngotran, 2016; Rogoff, 2017). Penggunaan teknologi informasi telah mengubah perilaku pelaku ekonomi untuk bertindak praktis, mudah, dan cepat sehingga dapat meminimalisir tingginya biaya transaksi dan akan memengaruhi perubahan output dan harga (Wulandari et al., 2016; Slozko \& Pelo, 2014; Khalaf, 2018). Disrupsi uang elektronik berimplikasi pada penerapan suku bunga rendah dan mendorong pertumbuhan kredit yang pada akhirnya berpengaruh pada stabilitas keuangan. Sementara dari stabilitas harga, perkembangan uang elektronik dapat memengaruhi kecepatan perputaran uang sehingga secara tidak langsung akan memengaruhi inflasi (Galí, 2015; Lenka \& Bairwa, 2016; Tule \& Oduh, 2017).

Beberapa studi mengenai dampak uang elektronik terhadap efektivitas kebijakan moneter menunjukkan hasil yang berbeda. Berangkat dari penelitian Sukmonkongsamoe (2019) yang menyebutkan bahwa uang elektronik meningkatkan efektivitas kebijakan moneter yang disebabkan karena pertumbuhan uang elektronik didukung oleh ketersediaan infrastruktur yang memadai dan keberadaan transaksi elektronik tidak menimbulkan disrupsi pada instrumen pembayaran konvensional. Sementara studi Hendry \& Zhu (2019) menjelaskan peningkatan uang elektronik dapat menyebabkan perubahan dalam kecepatan uang dan memberikan implikasi pada kurang efektifnya kebijakan moneter di negara yang menggunakan kuantitas uang sebagai target kebijakan moneter. Berbeda dengan hasil kajian Griffith \& Stephen (2004) dan Fabris (2019) yang menunjukkan bahwa jumlah uang elektronik yang masih sedikit dibandingkan dengan yang lain belum memberikan dampak yang signifikan terhadap kerangka kerja kebijakan moneter. Pada aras yang berbeda, analisis Greenwood-Nimmo 
(2009) cenderung memberi penekanan bahwa unless-money dapat memengaruhi suku bunga jangka pendek dan tidak akan memengaruhi efektivitas kebijakan moneter. Namun demikian, perubahan kecepatan uang elektronik akan berimplikasi pada kebijakan moneter dalam jangka panjang. Merujuk pada kajian Hendry \& Zhu (2019), memberi wawasan bahwasanya teori kuantitas uang berlaku dalam jangka panjang, dimana perubahan kecepatan uang akan berimplikasi pada inflasi atau perubahan harga. Dimensi yang agak berbeda diketengahkan oleh Kwon \& Park (2014) menyebutkan bahwa uang elektronik dapat mengurangi efektivitas kebijakan moneter. Pada saat suku bunga tinggi akan memengaruhi portofolio pemegang atau penerbit uang elektronik yang cenderung memegang uang elektronik lebih besar karena yield dari investasi akan lebih tinggi.

Terkait perilaku penggunaan uang elekstronik, Popovska-Kamnar (2014) dan Massaka (2019) dalam penelitiannya merekomendasikan untuk selalu menekankan pada pentingnya menjaga prinsip kehati-hatian dalam penggunaan uang elektronik. Namun, perspektif yang agak berbeda diungkap dalam penelitian Assenmacher \& Krogstrup (2018) dimana menyebutkan perlunya pemisahan uang tunai dari uang elektronik dalam meminimalisir kelemahan yang ada pada transaksi uang tunai dan perlunya disusun kerangka kebijakan yang hingga saat ini masih menjadi pertanyaan. Jelas bahwa relasi dan eksistensi uang elektronik dengan peluang terjadinya dinamisasi penggunaan dan risiko yang ditimbulkan menjadi subyek riil yang terjadi dalam perekonomian. Sebagai barang publik baru, uang elektronik menjadi ruang perdebatan tidak saja di ruas teoritis tetapi juga menghadirkan adanya implikasi kebijakan, khususnya di bidang moneter dan keuangan. Berangkat dari motivasi tersebut, maka secara spesifik studi ini berusaha menjawab dua pertanyaan empiris penting, yaitu bagaimana dampak uang elektronik (e-money) terhadap efektivitas kebijakan moneter di Indonesia? dan yang kedua adalah bagaimana dampak uang elektronik (e-money) terhadap pertumbuhan kredit perbankan di Indonesia?

\section{Metodologi}

Jenis data yang digunakan dalam studi ini adalah data sekunder runtun waktu dengan periode observasi adalah 2009.1-2019.12. Beberapa variabel yang digunakan dalam studi ini adalah Gross Domestic Product (GDP) atas harga konstan tahun dasar $2010\left(y_{t}\right)$, suku bunga kebijakan $\left(r p_{t}\right)$,inflasi domestik $\left(p i_{t}\right)$, kredit perbankan dalam Rupiah dan valuta asing $\left(c r_{t}\right)$, dan jumlah transaksi uang elektronik dalam satuan juta Rupiah $\left(u e_{t}\right)$. Sumber data diperoleh dari Statistik Ekonomi dan Keuangan Indonesia dari Bank Indonesia dan Bank Dunia.

Studi ini menggunakan metode Structural Cointegrating VAR (SCVAR) untuk melihat keterkaitan antar variabel melalui pengembangan model struktural jangka panjang yang dihasilkan dari hubungan dalam teori ekonomi. Hubungan jangka panjang diaproksimasi menggunakan persamaan log linier dengan variabel gangguan yang menggambarkan deviasi hubungan jangka panjang dari realisasinya dan disebut struktural kejutan jangka panjang (Maddala \& Lahiri, 
2009; Gujarati \& Porter, 2009; Wardhono et al., 2019b,c).

Model cointegrating VAR melibatkan restriksi jangka panjang sebagaimana dalam teori ekonomi. Model analisis ini berbeda dengan unrestricted VAR yang memasukkan restriksi dalam hubungan kointegrasi tanpa pandangan apriori yang jelas dari hubungan struktural ekonomi. Salah satu kelebihan structural cointegrating VAR adalah model didasarkan pada landasan teoritis yang koheren dengan properti jangka panjang makroekonomi. Keuntungan lain dari model structural cointegrating VAR adalah melibatkan secara eksplisit hubungan antara model residu yang diestimasi dan kejutan struktural dalam model ekonomi (Enders, 1995; Gujarati, 2003).

\section{Hasil dan Diskusi}

\subsection{Pola Keterkaitan Uang Elektronik dan Efektivitas Kebijakan Moneter}

Untuk melihat pola hubungan jangka panjang antara uang elektronik dan beberapa indikator makroekonomi adalah melalui pengujian kointegrasi dapat diartikan adanya hubungan jangka panjang dari dua atau lebih series yang tidak stasioner namun dapat bergerak bersama-sama dan perbedaan di antara series tersebut menuju stasioner (Durgun \& Timur, 2015). Pendekatan Johansen reduced rank test dapat digunakan untuk menguji eksistensi dari hubungan kointegrasi. Jumlah keterkaitan vektor kointegrasi menunjukkan adanya jumlah hubungan jangka panjang dalam sistem dan untuk mendukung prediksi teori. Berdasarkan hasil pengujian kointegrasi antar variabel dihasilkan adanya dua keterkaitan jangka panjang.

Model struktural jangka panjang structural cointegrating VAR memasukkan restriksi berdasarkan apriori teori. Penaksiran model dilakukan dengan memperhitungkan permasalahan identifikasi dalam sistem permodelan (Wardhono et al., 2019b,c). Permasalahan identifikasi terkait dengan penggunaan restriksi nol. Estimasi koefisien jangka panjang dapat dilakukan dengan memasukkan restriksi terhadap identifikasi secara over identified dalam model struktural. Uji restriksi dengan over-identifying untuk menguji restriksi dari reduced form secara parsimoni encompasses pada unrestricted reduced form. Pada saat proses identifikasi secara exact tidak terpenuhi, maka vektor kointegrasi harus diuji dengan over identifying sesuai dengan apriori informasi teori. Sebagaimana Harris (1995) menyebutkan pentingnya informasi masa lalu dari pelaku ekonomi menjadi dasar dalam memasukkan restriksi dalam model.

Pengujian restriksi dalam identifikasi berlebih (over identifying restrictions) adalah jumlah restriksi dimana $r$ jumlah keterkaitan jangka panjang. Validitas restriksi tambahan ini diuji dengan menggunakan Likelihood Ratio(LR) test dengan degree of freedom. Berdasarkan hasil uji kointegrasi Johansen yang mengindikasikan adanya dua keterkaitan dalam model, maka uji hipotesis restriksi keterkaitan jangka panjang dalam bentuk matrik adalah untuk variabel dengan persamaan 
model struktural sebagai berikut:

$$
\begin{gathered}
p i_{t}=\alpha_{0}+\alpha_{1} r p_{t}+\alpha_{2} u e_{t}+\varepsilon_{1} \\
u e_{t}=\beta_{0}+\beta_{1} y_{t}+\beta_{2} p i_{t}+\beta_{3} c r_{t}+\varepsilon_{2}
\end{gathered}
$$

Berdasarkan hasil estimasi jangka panjang yang terestriksi diperoleh nilai Likelihood Ratio (LR) $\chi^{2}(2)=0,308$. Hasil ini menunjukkan bahwa hipotesis nol tidak ditolak pada $\alpha=1 \%, 5 \%$, dan $10 \%$ dengan adanya keberadaan restriksi tambahan sehingga dapat dikatakan adanya restriksi tambahan adalah valid. Berikut adalah hasil penaksiran untuk model keseimbangan jangka panjang model Structural Cointegrating Vector Autoregressive (SCVAR).

Tabel 1: Hasil Estimasi Jangka Panjang Model SCVAR

\begin{tabular}{ccc}
\hline \hline Cointegrating Eq: & CointEq1 & CointEq2 \\
\hline Y(-1) & 0.000000 & -37.25685 \\
& & $(7.06176)$ \\
& & {$[-5.27586]$} \\
$\mathrm{RP}(-1)$ & -2.205695 & 0.000000 \\
& $(0.59461)$ & \\
& {$[-3.70950]$} & \\
$\mathrm{PI}(-1)$ & 1.000000 & 0.044226 \\
& & $(0.02871)$ \\
$\mathrm{CR}(-1)$ & 0.000000 & $1.54034]$ \\
& & $(0.77119)$ \\
& & {$[2.52270]$} \\
$\mathrm{UE}(-1)$ & -1.40538 & 1.000000 \\
& $(0.60328)$ & \\
$\mathrm{C}$ & {$[-2.32957]$} & \\
\hline Keterangan: angka dalam [ ] adalah nilai t-statistik
\end{tabular}

Berdasarkan penaksiran jangka panjang model menunjukkan bahwa dalam jangka panjang e-money $\left(u e_{t}\right)$ signifikan berpengaruh terhadap inflasi dengan hubungan yang terbalik dimana jika terjadi kenaikan uang elektronik maka akan menyebabkan inflasi turun, vice versa. Hal ini menunjukkan bahwa peningkatan transaksi uang elektronik sebagai media pembayaran digital cukup efektif terhadap stabilitas harga. Begitu pula terjadinya inflasi tidak berpengaruh secara signifikan terhadap transaksi uang elektronik. Hal ini memiliki arti bahwa motif masyarakat dalam menggunakan transaksi elektronik tidak terpengaruh oleh perubahan harga yang terjadi. Dukungan infrastuktur uang elektronik mengimbangi dampak kecepatan perputaran uang yang rentan terhadap terjadinya inflasi dalam jangka panjang (Wardhono et al., 2019a). Pertambahan kredit memberikan pengaruh yang cukup signifikan terhadap kenaikan transaksi uang elektronik (e-money) yang berarti preferensi masyarakat terhadap transaksi pembayaran digital semakin menguat. Namun pertumbuhan ekonomi dalam jangka panjang masih belum mampu mendongkrak kenaikan transaksi uang elektronik. 
Digitalisasi sistem pembayaran masih belum sepenuhnya diakses dengan baik (well-literate) seluruh segmen masyarakat. Masih terdapat masyarakat terutama di wilayah remote area yang masih memiliki inklusi dan literasi keuangan yang masih rendah (Wardhono et al., 2016,2017,2018).

Sementara dalam jangka pendek, penyesuaian terhadap koreksi kesalahan signifikan hanya pada persamaan pertumbuhan ekonomi dan kredit. Sejalan dengan hasil estimasi jangka panjang, peningkatan transaksi uang elektronik tidak mendorong kenaikan inflasi yang berarti bahwa dalam jangka pendek, percepatan uang elektronik dan perputaran uang cukup efektif dalam menjaga stabilitas harga. Dalam jangka pendek, seluruh determinan uang elektronik tidak signifikan secara statistik.

Impulse response bertujuan untuk melihat keterkaitan antar variabel yang digunakan dalam model menggunakan standard error metode Cholesky Decomposition (Wardhono et al., 2019c). Adanya kejutan pada variabel $i$ - th bukan hanya secara langsung memengaruhi variabel itu sendiri namun juga terhadap variabel endogen lainnya melalui dynamic lag structure VAR. Impulse response function mengidentifikasi pengaruh one-time shock terhadap satu inovasi pada nilai variabel endogen yang berjalan dan yang akan datang. Metode Cholesky menggunakan inverse Cholesky factor dari residual covariance matrix terhadap orthogonal impulse dengan memasukkan ordering variabel dalam VAR dan atribut seluruh komponen dalam VAR sistem.

Berdasarkan Gambar 2, pada awal periode adanya kejutan kenaikan inflasi menyebabkan kenaikan uang elektronik, yang berarti bahwa meningkatnya kemampuan daya beli masyarakat mendorong kenaikan permintaan masyarakat terhadap transaksi secara digital. Hal ini sejalan dengan semakin meningkatnya ragam jenis uang elektronik seperti kartu debet, kartu kredit maupun dompet digital. Namun setelah periode ketiga respons uang elektronik tidak berjalan searah dengan peningkatan inflasi meskipun hanya berlangsung sementara. Setelah periode keempat respons uang elektronik kembali searah dengan kenaikan inflasi dan bersifat permanen dalam mencapai kondisi steady state. Sedangkan respons suku bunga berbanding terbalik dengan transaksi uang elektronik. Sifat transaksi uang elektronik yang tidak inflasioner menyebabkan suku bunga cenderung turun dalam merespons stabilitas harga.

Sementara kenaikan pertumbuhan ekonomi pada awal periode diikuti oleh kenaikan transaksi uang elektronik pada awal periode dengan deviasi cukup kecil kemudian menurun. Setelah periode ketiga kembali bergerak searah dengan transaksi uang elektronik dan bersifat permanen dalam jangka panjang. Kondisi sejalan dengan dinamika perekonomian yang semakin cepat terlebih dalam era ekonomi digital yang menuntut kecepatan dan ketepatan dalam setiap mobilitas perekonomian. Kondisi ini berbanding terbalik dengan adanya peningkatan kredit pada awal periode tidak diikuti oleh kenaikan transaksi uang elektronik. Hal ini menunjukkan masih rendahnya integrasi transaksi elektronik dalam penggunaan alokasi kredit sehingga dibutuhkan kelengkapan infrastruktur secara terintegrasi kredit perbankan dalam bentuk transaksi elektronik. 
Tabel 2: Hasil Estimasi Jangka Pendek Model SCVAR

\begin{tabular}{|c|c|c|c|c|c|}
\hline Error Correction: & $\overline{\mathrm{D}(\mathrm{Y})}$ & $\overline{\mathrm{D}(\mathrm{RP})}$ & $\mathrm{D}(\mathrm{PI})$ & $\bar{D}(\mathrm{CR})$ & $\overline{\mathrm{D} \text { (UE) }}$ \\
\hline \multirow[t]{3}{*}{ CointEq1 } & $-5.39 \mathrm{E}-05$ & 0.012535 & -0.017342 & 0.001872 & 0.013797 \\
\hline & $(0.00021)$ & $(0.00673)$ & $(0.02893)$ & $(0.00047)$ & $(0.00807)$ \\
\hline & {$[-0.26066]$} & [ 1.86172$]$ & {$[-0.59950]$} & [ 3.94745] & [ 1.70961$]$ \\
\hline \multirow[t]{3}{*}{ CointEq2 } & 0.008040 & 0.102496 & -0.142674 & -0.008068 & -0.044742 \\
\hline & $(0.00201)$ & $(0.06531)$ & $(0.28059)$ & $(0.00460)$ & $(0.07828)$ \\
\hline & [ 4.00907] & [ 1.56939] & {$[-0.50848]$} & {$[-1.75378]$} & [-0.57159] \\
\hline \multirow[t]{3}{*}{$\mathrm{D}(\mathrm{Y}(-1))$} & 0.052442 & -1.444832 & -16.95971 & -0.105294 & 2.264627 \\
\hline & $(0.10007)$ & $(3.25878)$ & $(14.0007)$ & $(0.22956)$ & $(3.90582)$ \\
\hline & [ 0.52408] & {$[-0.44337]$} & {$[-1.21134]$} & {$[-0.45868]$} & [ 0.57981$]$ \\
\hline \multirow[t]{3}{*}{$\mathrm{D}(\mathrm{Y}(-2))$} & 0.198628 & 1.766907 & -20.77904 & 0.243591 & -0.286198 \\
\hline & $(0.09521)$ & (3.10052) & $(13.3208)$ & $(0.21841)$ & $(3.71613)$ \\
\hline & [ 2.08630] & [ 0.56988$]$ & [-1.55989] & [ 1.11529] & {$[-0.07701]$} \\
\hline \multirow[t]{3}{*}{$\mathrm{D}(\mathrm{RP}(-1))$} & -0.005896 & 0.212369 & 0.747960 & 0.015247 & -0.056181 \\
\hline & $(0.00313)$ & (0.10178) & $(0.43728)$ & $(0.00717)$ & $(0.12199)$ \\
\hline & {$[-1.88664]$} & [ 2.08656] & [ 1.71049] & [ 2.12661] & {$[-0.46054]$} \\
\hline \multirow[t]{3}{*}{$\mathrm{D}(\mathrm{RP}(-2))$} & -0.002304 & 0.162778 & -0.311334 & 0.008545 & -0.176705 \\
\hline & $(0.00315)$ & (0.10269) & $(0.44118)$ & $(0.00723)$ & $(0.12308)$ \\
\hline & {$[-0.73083]$} & [ 1.58518$]$ & {$[-0.70569]$} & [ 1.18130] & [-1.43573] \\
\hline \multirow[t]{3}{*}{$\mathrm{D}(\mathrm{PI}(-1))$} & -0.000509 & 0.026148 & 0.273288 & -0.000482 & 0.012573 \\
\hline & $(0.00072)$ & $(0.02347)$ & $(0.10083)$ & $(0.00165)$ & $(0.02813)$ \\
\hline & {$[-0.70662]$} & [ 1.11416$]$ & [ 2.71038] & {$[-0.29174]$} & [ 0.44698 ] \\
\hline \multirow[t]{3}{*}{$\mathrm{D}(\mathrm{PI}(-2))$} & -0.000268 & -0.025267 & -0.102806 & -0.002211 & 0.003991 \\
\hline & $(0.00073)$ & $(0.02368)$ & $(0.10175)$ & $(0.00167)$ & $(0.02839)$ \\
\hline & {$[-0.36888]$} & [-1.06690] & {$[-1.01039]$} & {$[-1.32559]$} & [ 0.14059] \\
\hline \multirow[t]{3}{*}{$\mathrm{D}(\mathrm{CR}(-1))$} & 0.057286 & 1.204210 & 3.766490 & -0.193533 & -0.575044 \\
\hline & $(0.04548)$ & $(1.48110)$ & $(6.36328)$ & $(0.10433)$ & $(1.77518)$ \\
\hline & [ 1.25961$]$ & [ 0.81305] & [ 0.59191] & {$[-1.85494]$} & {$[-0.32394]$} \\
\hline \multirow[t]{3}{*}{$\mathrm{D}(\mathrm{CR}(-2))$} & 0.076680 & 0.054446 & 6.731439 & -0.185798 & -1.620658 \\
\hline & $(0.04526)$ & $(1.47383)$ & $(6.33206)$ & $(0.10382)$ & $(1.76647)$ \\
\hline & [ 1.69435$]$ & [ 0.03694] & [ 1.06307] & {$[-1.78959]$} & {$[-0.91746]$} \\
\hline \multirow[t]{3}{*}{$\mathrm{D}(\mathrm{UE}(-1))$} & 0.001373 & 0.053382 & -0.652149 & 0.010940 & -0.190146 \\
\hline & $(0.00301)$ & $(0.09801)$ & $(0.42110)$ & $(0.00690)$ & $(0.11748)$ \\
\hline & [ 0.45613] & [ 0.54463] & [-1.54868] & [ 1.58446$]$ & [-1.61861] \\
\hline \multirow[t]{3}{*}{$\mathrm{D}(\mathrm{UE}(-2))$} & 0.001748 & -0.022008 & -0.985749 & 0.001726 & -0.310083 \\
\hline & $(0.00275)$ & $(0.08946)$ & $(0.38433)$ & $(0.00630)$ & $(0.10722)$ \\
\hline & [ 0.63630$]$ & {$[-0.24601]$} & [-2.56482] & [ 0.27393$]$ & [-2.89207] \\
\hline \multirow[t]{3}{*}{$\mathrm{C}$} & -0.000982 & -0.035366 & -0.041962 & 0.016993 & 0.074641 \\
\hline & $(0.00100)$ & $(0.03252)$ & $(0.13971)$ & $(0.00229)$ & $(0.03897)$ \\
\hline & [-0.98363] & [-1.08759] & {$[-0.30036]$} & [ 7.41848] & [ 1.91512$]$ \\
\hline$R$-squared & 0.277480 & 0.310629 & 0.256002 & 0.215839 & 0.207773 \\
\hline Adj. R-squared & 0.183238 & 0.220711 & 0.158959 & 0.113557 & 0.104439 \\
\hline Sum sq. resids & 0.002280 & 2.418544 & 44.64229 & 0.012001 & 3.474310 \\
\hline S.E.equation & 0.004979 & 0.162137 & 0.696593 & 0.011421 & 0.194330 \\
\hline F-statistic & 2.944336 & 3.454578 & 2.638023 & 2.110234 & 2.010696 \\
\hline Log likelihood & 414.7228 & 48.97817 & -104.0864 & 327.5378 & 29.96108 \\
\hline Akaike AIC & -7.651863 & -0.685298 & 2.230217 & -5.991196 & -0.323068 \\
\hline Schwarz SC & -7.323278 & -0.356713 & 2.558803 & -5.662611 & 0.005517 \\
\hline Mean dependent & 0.001524 & -0.033333 & -0.063714 & 0.012381 & 0.039905 \\
\hline S.D. dependent & 0.005509 & 0.183668 & 0.759575 & 0.012131 & 0.205349 \\
\hline
\end{tabular}

Sumber: Bank Indonesia (2019), diolah

Keterangan: angka dalam [ ] adalah nilai t-statistik 
Response to Cholesky One S.D. Innovations

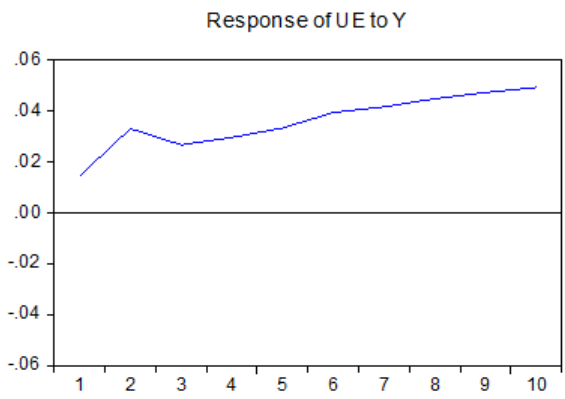

Response of UE to RP

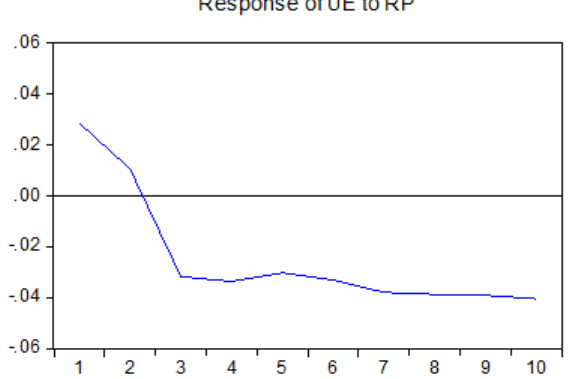

Response of UE to PI

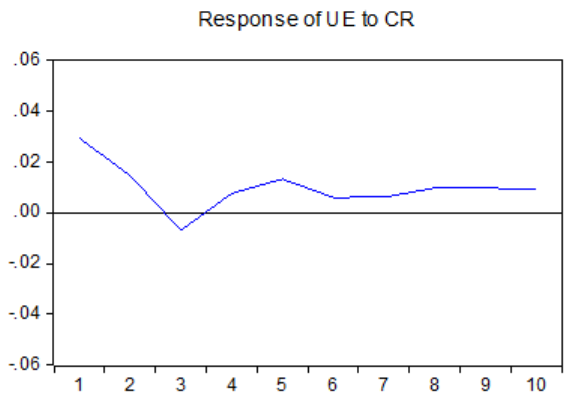

Gambar 2: Respons Transaksi Uang Elektronik terhadap Indikator Makroekonomi Sumber: Bank Indonesia (2019), diolah

Gambar 2 juga menunjukkan respons inflasi dengan adanya kenaikan transaksi uang elektronik tidak bersifat inflasioner pada awal periode, dan mengalami fluktuasi hingga periode ketujuh dan kemudian bersifat permanen menuju kondisi stabil (steady state). Kecepatan perputaran uang elektronik terhadap inflasi mampu dikendalikan dengan semakin meningkatnya suku bunga kebijakan sebagai instrumen suku bunga kebijakan jangka pendek dan memengaruhi permintaan agregat masyarakat. Sementara dalam jangka panjang, adanya kenaikan uang elektronik menyebabkan kecenderungan menurunnya suku bunga. Hal ini berkaitan dengan korelasi uang elektronik yang tidak bersifat inflatoir sehingga suku bunga cenderung bergerak turun. Namun di sisi lain, rendahnya suku bunga dapat berpotensi risiko terhadap instabilitas sistem keuangan akibat hadirnya moral hazard pelaku ekonomi.

Kenaikan transaksi uang elektronik dalam jangka panjang belum mampu diikuti oleh pertumbuhan ekonomi secara masif, meskipun pada awal periode adanya kejutan uang elektronik cukup mendongkrak pertumbuhan ekonomi pada level hingga 2,8 persen sebelum mencapai steady state. Keberadaan uang elektronik masih belum mampu mengatasi terjadinya digital divide, yakni distribusi yang belum merata dalam akses, penggunaan, ataupun dampak teknologi 


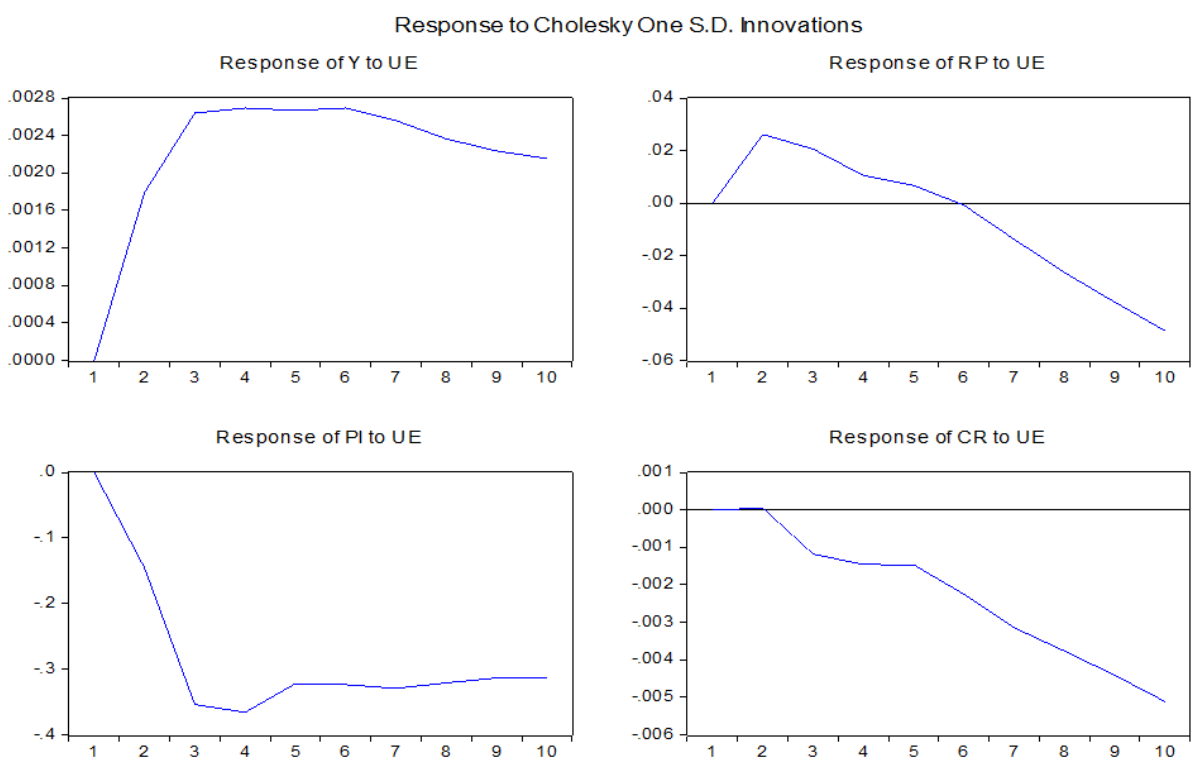

Gambar 3: Respons Indikator Makroekonomi terhadap Transaksi Uang Elektronik Sumber: Bank Indonesia (2019), diolah

dalam segmen masyarakat yang berbeda baik sosial, geografis, maupun geopolitik.

Sementara pada indikator sistem keuangan, keberadaan uang elektronik (e-money) belum memberikan dampak terhadap pertumbuhan kredit yang ditunjukkan dengan arah berbanding terbalik pada impulse response. Hal ini menunjukkan masih lemahnya korelasi uang elektronik dan pertumbuhan kredit. Tingginya permintaan masyarakat terhadap uang elektronik sebagai alat transaksi pembayaran belum diikuti permintaan kredit.

\subsection{Implikasi Kebijakan}

Alat pembayaran yang inovatif dan praktis berupa uang elektronik diharapkan dapat membantu kelancaran alur pembayaran aktivitas ekonomi yang bersifat masal dan cepat sehingga perkembangannya dapat membantu kelancaran transaksi ekonomi (Bank Indonesia, 2019). Perkembangan uang elektronik diharapkan pula dapat digunakan sebagai alternatif alat pembayaran non tunai yang dapat menjangkau masyarakat yang selama ini belum mempunyai akses kepada sistem perbankan. Penyelenggaraan Uang Elektronik telah diatur dalam Peraturan Bank Indonesia (PBI) Nomor 20/6/PBI/2018 tentang Uang Elektronik.Terdapat beberapa manfaat dari uang elektronik, tetapi di sisi lain terdapat beberapa risiko yang perlu disikapi dengan kehati-hatian dari pengguna produk 
keuangan berbasis digital yakni sebagai berikut (Bank Indonesia, 2019):

1. Risiko uang elektronik bisa hilang dan dapat digunakan oleh pihak lain karena uang elektronik sama seperti uang tunai, jika hilang, maka tidak dapat diklaim kepada penerbit.

2. Risiko karena masih kurang pahamnya pengguna maupun merchant dalam menggunakan uang elektronik, seperti penggunaan double charge pada mesin electronic data capture (EDC) untuk transaksi yang sama sehingga tercatat dua kali transaksi.

Maka upaya edukasi pada masyarakat secara intensif sangat penting untuk dilakukan sehingga bukan hanya memberikan akses atau inklusi namun juga secara literasi, masyarakat menjadi terliterasi (well literate), baik dalam alokasi penggunaan, teknik penggunaan hingga mitigasi terhadap risiko kegagalan atau penyalahgunaan.

\section{Kesimpulan dan Rekomendasi}

\subsection{Kesimpulan}

Uang elektronik (e-money) tidak menimbulkan dampak inflasioner terhadap stabilitas harga baik dalam jangka panjang dan jangka pendek. Instrumen suku bunga cukup efektif dalam mengendalikan kecepatan perputaran uang yang berasal dari uang elektronik. Sehingga transaksi uang elektronik memberikan dampak yang efektif terhadap kebijakan moneter. Kenaikan pertumbuhan ekonomi dalam jangka panjang tidak memberikan pengaruh terhadap kenaikan transaksi uang elektronik (e-money), begitu pula dalam jangka pendek tidak memberikan dampak yang signifikan. Percepatan pertumbuhan ekonomi terhadap pembayaran digital masih belum sepenuhnya dirasakan oleh seluruh masyarakat oleh karena tingkat inklusi keuangan yang masih rendah. Uang elektronik tidak memberikan dampak yang signifikan dalam mendorong pertumbuhan kredit dalam jangka pendek, namun dalam jangka panjang potensi kenaikan kredit akan diikuti atau berbanding lurus dengan meningkatnya transaksi keuangan secara digital.

\subsection{Rekomendasi}

Akselerasi percepatan transaksi digital sebaiknya disertai dengan ketersediaan infrastruktur yang memadai, memperkuat regulasi dan memberlakukan prinsip kehati-hatian dalam memitigasi risiko disrupsi digital. Oleh karenanya Bank Indonesia secara intensif melakukan kerjasama dalam bentuk open banking terutama dengan perusahaan financial technology untuk meminisasi perbankan maya (shadow banking) dan risiko penipuan. Percepatan sistem pembayaran digital sepatutnya mampu membangun ekosistem yang merata baik secara inklusi maupun literasi. Inklusivitas masyarakat pada akses dan produk perbankan terus ditingkatkan, terlebih di wilayah pelosok (remote area) yang sulit mengakses sistem keuangan elektronik, yang disebabkan kendala geografis maupun budaya. 


\section{Daftar Pustaka}

[1] Assenmacher, K., \& Krogstrup, S. (2018). Monetary policy with negative interest rates: Decoupling cash from electronic money. IMF Working Paper, 18/191. International Monetary Fund. https://www.imf.org/en/Publications/WP/Issues/2018/08/27/ Monetary-Policy-with-Negative-Interest-Rates-Decoupling-Cash-from-ElectronicMoney-46076.

[2] Bank Indonesia. (2019). Laporan perekonomian Indonesia 2019: Sinergi, transformasi, dan inovasi menuju Indonesia maju. https://www.bi.go.id/id/publikasi/ laporan-tahunan/perekonomian/Documents/9_LPI2019.pdf.

[3] Durgun, Ö., \& Timur, M. C. (2015). The effects of electronic payments on monetary policies and central banks. Procedia - Social and Behavioral Sciences, 195, 680-685. doi: 10.1016/j.sbspro.2015.06.271.

[4] Enders, W. (1995). Applied econometric time series. John Wiley \& Sons.

[5] Fabris, N. (2019). Cashless society - The future of money or a utopia?. Journal of Central Banking Theory and Practice, 8(1), 53-66. doi: https://doi.org/10.2478/jcbtp2019-0003.

[6] Fatmawati, M. N. R., \& Yuliana, I. (2019). Pengaruh transaksi non tunai terhadap jumlah uang beredar di Indonesia tahun 2015-2018 dengan inflasi sebagai variabel moderasi. Ekspansi: Jurnal Ekonomi, Keuangan, Perbankan dan Akuntansi, 11(2), 269-283. doi: https://doi.org/10.35313/ekspansi.v11i2.1608.

[7] Forrest, J. Y. L., Ying, Y., \& Gong, Z. (2018). A general theory of international money. In J. Y. L. Forrest, Y. Ying, \& Z. Gong, Currency wars: Offense and defense through systemic thinking (pp. 475-500). Springer, Cham.

[8] Galí, J. (2015). Monetary policy, inflation, and the business cycle: An introduction to the new Keynesian framework and its applications (2nd edition). Princeton University Press.

[9] Greenwood-Nimmo, M. (2009). Reassessing the 'Threat'of E-Money: New Evidence from the Euro Area. http:/ /www.greenwoodeconomics.com/emoney.pdf.

[10] Griffith, R. \& Stephen F. (2004). Electronic Money and Monetary Policy. Southwestern Economic Proceedings, 31(2), 47-56. http:/ / swer.wtamu.edu/sites/default/files/Data/ 47\%20-\%2056-216-800-1-PB.pdf.

[11] Gujarati, D. N. (2003). Basic Econometrics (4th Edition). Singapura: McGraw-Hill.

[12] Gujarati, D. N., \& Porter, C. D. (2009). Basic Econometrics (5th Edition). New York: McGraw-Hill.

[13] Harris, R. I. (1995). Using cointegration analysis in econometric modelling. Prentice Hall.

[14] Hendry, S. \& Zhu, Y. (2019). A framework for analyzing monetary policy inan economy with e-money. Bank of Canada Staff Working Paper 2019-1. Bank of Canada. https://www.bankofcanada.ca/2019/01/staff-working-paper-2019-1/.

[15] Ismanda, F. (2019). Analisis pengaruh APMK dan e-money sebagai instrumen pembayaran non tunai terhadap tingkat suku bunga dan pertumbuhan ekonomi di Indonesia. Jurnal Dinamika Ekonomi Pembangunan, 2(2), 202-212. doi: https://doi.org/10.33005/jdep.v2i2.94.

[16] Khalaf, H. H. (2018). The impact of electronic money on the effectiveness of monetary policy. Academy of Entrepreneurship Journal, 24(3), 1-16.

[17] Kwon, O., \& Park, J. (2018). E-money: Legal restrictions theory and monetary policy. BOK Working Paper 2018-17. Bank of Korea. https:/ /www.bok.or.kr/eng/bbs / B0000268 $/$ view.do?nttId=10045237\&menuNo=400067\&pageIndex $=1$.

[18] Lenka, S. K., \& Bairwa, A. K. (2016). Does financial inclusion affect monetary 
policy in SAARC countries?. Cogent Economics E Finance, 4(1), 1127011. doi: https://doi.org/10.1080/23322039.2015.1127011.

[19] Lintangsari, N. N., Hidayati, N., Purnamasari, Y., Carolina, H., \& Ramadhan, W. F. (2018). Analisis pengaruh instrumen pembayaran non-tunai terhadap stabilitas sistem keuangan di Indonesia. Jurnal Dinamika Ekonomi Pembangunan, 1(1), 47-62. doi: https://doi.org/10.14710/jdep.1.1.47-62.

[20] Maddala, G. S., \& Lahiri, K. (2009). Introduction to econometrics (4th Edition). United Kingdom: Wiley.

[21] Massaka, A. P. (2019). Monetary policy its instruments and convergence of its objectives: Case of Angola 2005-2017. Journal of Economics and Public Finance, 5(2), 161-182. doi: https://doi.org/10.22158/jepf.v5n2p161.

[22] Ngotran, D. (2016). The e-monetary theory. MPRA Paper 77206. Munich Personal RePEc Archive. https://mpra.ub.uni-muenchen.de/77206/.

[23] Popovska-Kamnar, N. (2014). The use of electronic money and its impact on monetary policy. Journal of Contemporary Economic and Business Issues, 1(2), 79-92.

[24] Rogoff, K. S. (2017). The curse of cash: How large-denomination bills aid crime and tax evasion and constrain monetary policy. Princeton University Press.

[25] Slozko, O., \& Pelo, A. (2014). The electronic payments as a major factor for futher economic development. Economics and Sociology, 7(3), 130-140. doi: dx.doi.org/10.14254/2071-789X.2014/7-3/10.

[26] Sukmonkongsamoe, C. (2019). Rise in e-money adoption and its monetary policy implications: A cross-country analysis. https:/ /www.bot.or.th/Thai/Segmentation/ Student/setthatat/DocLib_Settha_Paper_2559/B_Doc_Prize5_2559.pdf.

[27] Tule, M. K., \& Oduh, M. O. (2017). Financial innovations and the future of monetary policy in Nigeria. Economics of Innovation and New Technology, 26(5), 453-476. doi: https://doi.org/10.1080/10438599.2016.1229854.

[28] Wardhono, A., Qori'ah, C. G., \& Indrawati, Y. (2016). The determinants of financial inclusion: Evidence from Indonesian districts. International Journal of Economic Perspectives, 10(4), 472-483.

[29] Wardhono, A., Qori'ah, C. G., \& Indrawati, Y. (2017). Studi komparatif inklusi keuangan di Kabupaten Jember dan Bondowoso: Identifikasi penyebab dan strategi pengembangan kebijakan. Universitas Jember Press.

[30] Wardhono, A., Indrawati, Y., \& Qori'ah, C. G. (2018). Inklusi keuangan dalam persimpangan kohesi sosial dan pembangunan ekonomi berkelanjutan. Pustaka Abadi.

[31] Wardhono, A., Indrawati, Y., Qoriah, C. G., \& Nasir, M. A. (2019a). Perilaku kebijakan bank sentral di Indonesia. Pustaka Abadi.

[32] Wardhono, A., Indrawati, Y., Qoriah, C. G., \& Nasir, M. A. (2019b). Analisis data time series dalam model makroekonomi. Pustaka Abadi.

[33] Wardhono, A., Indrawati, Y., Nasir, M. A., \& Qori'ah, C. G. (2019c). Structural cointegrating vector autoregression approach in macroeconomic model. Paper presented at The 5th SBE International Conference on Business and Economy 2019, March 13-14, Universitas Katolik Soegijapranata, Semarang, Indonesia.

[34] Wulandari, D., Soseco, T., \& Narmaditya, B. S. (2016). Analysis of the use of electronic money in efforts to support the less cash society. International Finance and Banking, 3(1), 1-10. doi: https://doi.org/10.5296/ifb.v3i1.8802. 
this page intentionally left blank 